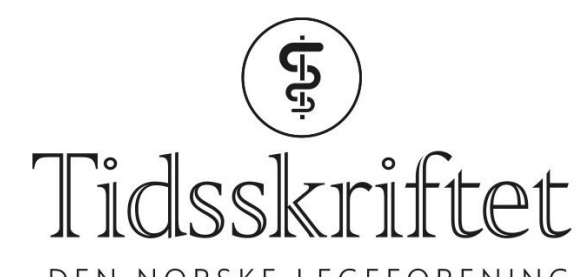

DEN NORSKE LEGEFORENING

\title{
Spå eller forstå?
}

RETTELSE

KATHRINE FREY FRØSLIE

JO RØISLIEN

E-post: jo@joroislien.no

Tidsskr Nor Legeforen 2018; 138: 657

I Tidsskriftet nr. 9/2018, s. 657, skal forfatterrekkefølgen være:

Kathrine Frey Frøslie

Jo Røislien

Vi beklager feilen, den er rettet på nett.

Publisert: 25. juni 2018. Tidsskr Nor Legeforen. DOI:10.4045/tidsskr.18.0488

(C) Tidsskrift for Den norske legeforening 2020. Lastet ned fra tidsskriftet.no 